\title{
Small-Scale Aid Donors, Agribusiness, And The Zambian Export Sector
}

John R Ledgerwood, Embry-Riddle Aeronautical University, USA Stephen N. Morgan, Fulbright Scholar to Zambia, Africa

\begin{abstract}
Production of high value agriculture and natural products has become a key instrument in economic development programs to accomplish the dual objectives of raising rural incomes and conserving valuable environmental resources. Rapid growth in global demand for organic and natural products has provided a strong economic incentive for small scale aid agencies to expand into this niche market. Through this analysis we investigate the economic impact that aid funded agricultural production has had on rural residents of Zambia and how this development strategy allows small scale aid donors to capitalize on the business and export opportunities in the Central African region. We want to determine what practices, if any, can be applied to other small development organizations working in economically deprived countries. The case for this analysis is Enright Flight Ministries, Inc. (EFM), a 501(c)3 not-for-profit organization with the dual objectives of promoting economic development and evangelism in Zambia. EFM has over 20 years experience in establishing agricultural production programs to support economic development in the Democratic Republic of the Congo and Zambia. Our focus will be on 5 major EFM agribusiness ventures: African hardwood products, organic honey, aloe vera, bananas, and fisheries. Analysis of the financial statements of EFM will be relied on to provide an accurate view of total investment into the various agricultural projects. Levels of investment will be discussed in light of the current global demand for each particular product. We break down project reports to determine what benefits accrue to both farm and non-farm rural Zambians. This financial analysis will be supplemented with semi-structured interviews performed with EFM administrative staff and aid recipients during the period August - December 2011. Special attention is paid to how aid recipients perceive the program benefits.
\end{abstract}

Keywords: International Business; Agribusiness; Non-Profit; Zambia; Small-Scale Aid Donors

\section{INTRODUCTION}

nvestment in the agricultural sector has become a popular means for small scale aid donors to leverage limited budgets to achieve significant and sustainable levels of economic development in many poor nations. Working primarily in agrarian societies, agricultural markets are the obvious choice for most small donors because of the immediate access to local and national markets. In addition there is the ability to tap into the human capital (production knowledge) of the rural populations these organizations aim to serve. Recent successes in utilizing niche agricultural enterprises to achieve both increases in local incomes and environmental conservation goals also add to the investment appeal for organizations which often face a lengthy list of organizational objectives (Reardon 1995). Additionally, robust demand for high-value agricultural products in both developed and emerging markets provide a very strong economic incentive for aid donors to leverage their funds in the agricultural and natural resource sector.

Enright Flight Ministries Inc. (EFM) is a 501(c) 3 non-profit organization that can be classified as a private small scale aid organization with annual disbursements totaling under 1 million dollars. EFM operates with the dual objectives of promoting economic development and evangelism. With headquarters in the United States, field operations are currently based in the Copperbelt Province of northern Zambia. Major activities are divided into a pastor training program, support for local churches/congregations, and agricultural enterprises. The organization 
relies heavily on the business activities to benefit the community through employment, knowledge transfer, and income stability while providing sustainable revenue streams that supplement donations from private individuals in the United States. We focus on EFM's 5 major production and processing ventures: hardwood/timber, honey, aloe vera, bananas, and fisheries.

This paper will analyze the agribusiness efforts of EFM and the economic effects which they have on rural Zambians. Particular attention will be paid to how EFM investment in agriculture takes advantage of (or ignores) the market and export opportunities available in sub-Saharan Africa. We also seek to find what practices, if any, can be applied to other small scale development programs throughout the region. Financial information used in this analysis was gathered from the financial records and statements of EFM and the agribusiness ventures during the period 2004 to the present. Supplementing this information are semi-structured interviews in Zambia with EFM field staff and project beneficiaries collected from August - December 2011.

\section{ZAMBIA IN THE GLOBAL ECONOMY}

An understanding of Zambia's current position in global markets is imperative to fully comprehend the ramifications of any investment in agricultural production may have on the local and national economy. Unique within sub-Saharan Africa, Zambia has maintained a peaceful and stable democracy since gaining independence from the United Kingdom in 1964. Despite this political advantage, Zambia has been plagued with poor infrastructure, political instability in neighboring countries, and crippling poverty rates that have hampered both investment and market access for many nationally produced products. The major exception to this, as is the case for most resource rich countries, has been mining. As Africa's largest producer of copper the economy is largely dependent upon the extraction of this resource in the heavily industrialized and appropriately named Copperbelt Province. In 2010 Zambia exported $\$ 7.2$ billion in copper which accounted for $70 \%$ of export earnings and was the main driver of a GDP growth rate in excess of 7\% (Palitza 2011). Rich copper deposits attract huge influxes of foreign direct investment - $\$ 1$ billion from China in 2010 alone - and tend to overshadow another significant resource endowment: Land (Palitza 2011). Zambia is uniquely well suited for significant levels of agricultural production with estimates suggesting that as much as 58\% of land has "medium to high potential for agriculture" while only $14 \%$ is currently under cultivation (World Bank 2009). At present the World Bank estimates that agriculture accounts for $40 \%$ of GDP and employs $67 \%$ of the labor force mostly in the form of small subsistence farming operations (World Bank 2009).

Seeking greater diversification in the national economy, Zambia has been an active proponent of international trade agreements as a means to develop new export sectors. While many of these agreements were driven by a desire to develop strong manufacturing sectors, membership in these global and regional trade pacts have provided new opportunities for agricultural exports as well. At present, the Zambian Revenue Authority lists 4 major agreements that impact the Zambian export sector:

1. General System of Preferences (GSP) - a policy enacted through the World Trade Organization (WTO) allowing developed countries to grant preferential treatment to trading partners among the least developed countries.

2. African Growth and Opportunity Act (AGOA) - provides trade preferences and duty free access to the U.S. market for certain goods in addition to GSP policies.

3. Southern Africa Development Community (SADC) - an intergovernmental organization promoting social and economic cooperation. In 2008 it joined COMESA to allow for free trade between 26 African states.

4. Common Market for Eastern and Southern Africa (COMESA) - free trade agreement among 19 member states across Africa. In 2008 it joined with SADC to expand the free trade area to 26 countries.

These agreements all have some provisions for agricultural production, and they help to improve access to both emerging and developed markets where the demand for high-quality and high-value products remains strong. Keeping these influences in mind, we now discuss the activities of EFM. 


\section{AFRICAN HARDWOODS}

One of the earliest business efforts of EFM was to engage in the processing of African hardwoods purchased throughout central Africa. Purchasing uncut timber, the wood-shop, as it is referred to in EFM financial documents, adds a tremendous level of value to the wood by transforming the timber into high quality furniture and construction materials (doors, trusses, etc.). On the production of wooden doors alone, EFM maintains a selling price of $\$ 300$ which represents $400 \%$ value-added. Because these product lines are custom built and are aimed primarily at industrial groups and businesses in the Copperbelt region it is natural that they have found a large market for the products among the mining community. EFM has currently invested approximately $\$ 800,000$ into capital equipment and training for the shop. Unfortunately the recent entry of Chinese and Russian corporations into the mining sector have seen companies importing their own building materials diminishing some of the historically higher demand that the wood-shop relied on. A reorganization in 2011 is attempting to refocus efforts on creating and marketing products to sub-Saharan Africa's growing middle class who is beginning to demand locally produced luxury products as their disposable income rises. This has resulted in new exports to the South African market with plans to build this consumer base in the coming months.

The major beneficiaries of this program are both farm and non-farm rural Zambians who are employed in processing and manufacturing. Operating year-round, the wood-shop provides a source of income for individuals who are often looking to supplement income generated by subsistence farming activities, especially in the "dry" or winter season. Throughout discussions with wood-shop employees a constant theme was the investment that was made possible through this venture. The workers credited this job with allowing them to save money to build homes, purchase farmland, and buy farm supplies. Another common theme was the use of the income to finance an education for one or more children in the household. Drawbacks include the reliability of the market. Because the products are so heavily marketed to the mining companies, demand and sales have been inversely related to the price of copper. When copper prices dramatically fell in 2008 the wood-shop saw demand for the products all but disappear which reduced the number of employees from 120 to 50. Additionally, this source of income represents a major shift of activities for the individual and leaves less time for subsistence farming activities. This time diversion is minimal however, because in Zambia women are the primary source of subsistence farming labor.

\section{HONEY}

With development in mind, one of the fastest growing businesses in the EFM portfolio is the production of organic honey. Utilizing a modified Kenyan top-bar apiary, EFM has been successful in partnering with small scale farmers throughout the region to produce 20 tons of honey annually. This business is structured as a cooperative where EFM provides all of the capital (apiary, swarm boxes, safety equipment, training, processing) and guarantees the purchase of the honey at a specified price. At present the honey is purchased from the farmer for approximately $\$ 1$ per kilogram and sold in local retail stores at \$3 per kilogram. Intending to export this product to the European market, EFM has instead diverted the entire product supply to meet stronger than anticipated local and national demand. Administrative staff is currently in the process of obtaining European organic certification as estimates see the supply increasing to support export shipments within the next 3 years.

An important aspect to the financing of this program was EFM's ability to secure matching grant funding from the German national development agency formerly known as German Technical Assistance (GTZ). In 2009 GTZ provided $\$ 250,000$ in matching funding to the honey business bringing the total investment in the program to $\$ 950,000$. This money has brought the total number of apiaries placed in the field to 7000 under the management of 1400 farmers.

The small-scale producers who receive apiaries derive the most significant benefits from honey operations. Supplemental income for the family unit was the chief benefit cited by producers. As an interesting addition, most producers also mentioned that they felt they received a very good return on their investment for the time they put in. At present, each farmer spends approximately 2 hours per week tending to 5 hives with significantly more during the two harvest periods each year. This means that the hives, for most of the year, are not a significant distraction from other more traditional income generating activities. Because much of the farming labor in Zambia is provided by women, the vast majority of apiary owners recruited by the program are also women. When the EFM honey 
business purchases the honey from the producers, the income is paid directly to the apiary owner and not the traditional male head of household. This pay scheme has naturally begun to address inequality in capital ownership between men and women in rural communities, and in some cases has dramatically altered the structure of the family. Several female farmers have used the income to purchase additional property and expand their own farming activities.

\section{ALOE VERA}

As the smallest business enterprise in the EFM portfolio, the production of Aloe Vera employees only 20 individuals and is aimed at producing for retail outlets throughout Central Africa. The product is a 500mg bottle of aloe vera gel for human consumption. Selling for $\$ 4.50$, aloe is considered among local populations to be a medicinal remedy for most ailments. EFM has invested $\$ 400,000$ into the project to plant several hectares of aloe and is currently supplying local retail outlets, supermarkets, and gas stations with 3,000 bottles of product per month. Due to the small size of this venture there is limited export potential.

Due to the small nature of the business and the specialized product, it is the firm belief of the EFM administrators and the project employees that the real beneficiaries of this program are the consumers. EFM struggles to keep up with supply, and maintains a low selling price to ensure that the aloe vera is affordable for the average rural farmer in Zambia. This pricing strategy keeps profits low. The most popular belief to consumers we interviewed is that the aloe "helps the immune system" and is "good for people with HIV". With Zambia's tragically high rate of HIV infections, the manager of EFM's wholesale shop stated that most, if not all, medicinal purchases were by individuals seeking to alleviate the symptoms of HIV. Because of this strong regional assertion of the health benefits of aloe vera a strong secondary market has risen with the use of aloe vera in animal feed. Local farmers who are raising chickens, cows, and pigs have begun to purchase the gel in large quantities to mix with commercially purchased feed products. Farmers claim to have less incidence of disease, fewer abnormalities in the animals, and a faster time to market when aloe vera is used. There have been no studies supporting these findings, but the common practice has spurred aloe sales.

\section{BANANAS}

Banana production has been a difficult and knowledge intensive enterprise for EFM. Total EFM investment into the business is $\$ 200,000$ with much of this spent on testing varieties and practices for producing bananas in Zambia. Highly susceptible to disease and pests, EFM employs only 9 individuals so that quality control can be strictly maintained. There is also a strict grading system for the product, with bananas graded A, B, C or no grade and priced accordingly. Current banana operations span 11 hectares and the entire supply is strictly for the wholesale market with $\mathrm{A}, \mathrm{B}$, and $\mathrm{C}$ grade bananas being sold to local resellers and no grade bananas sold for animal feed. There is limited export potential for the banana business.

The local retailers who buy the bananas glean the most benefits from this project. Over 120 women from local townships come every day to purchase 5 - 10 kilograms of bananas to take to the market for sale. The markup on wholesale is $100 \%$ which brings the total price to $\$ 1.35$ per kilogram. Much like the honey program, this revenue stream serves to diversify the household income away from reliance on subsistence farming and represents a payment directly to a female member of the household. In talking with many women who resell the bananas, this income is often used to pay for the tuition and school uniforms for their children's education. Many women also credit the addition of bananas as helping them to sell more of their own farm's products at the market. This occurs because of the grading system employed by EFM where the women are able to purchase higher quality bananas than virtually all competitors in the region. When customers seek out these high quality fruits, they are more likely to purchase something else from the vendor.

\section{FISHERIES}

The newest business endeavor of EFM has been investment into the creation of fish ponds to farm organic tilapia and bring it to market. With a total investment of $\$ 800,000$ there are 18 half hectare fish ponds in operation with plans to expand with an additional 80 ponds. As with the honey project, this venture has benefited from a 
matching grant funding program administered by the development organization Africare. The 18 ponds are producing approximately 0.5 tons of tilapia fingerlings per day with the goal after expansion to be 6 tons per day. The main innovation driving this business is the establishment of a hatchery to raise the fish and minimize mortality rates. Investment in structures to cover and insulate half of the ponds in the winter months has allowed the business to maintain production throughout the year. This product has massive regional export potential in Central Africa but options diminish with the distance. The main problem is the processing which would be required to enter the European Union. This process would require approximately $\$ 2$ million in additional investment to meet the high standards imposed on packaged seafood and fish products. In the Democratic Republic of the Congo however, there are very few processing requirements and consumers actually prefer to purchase the fish dried, salted, and whole. At present there are many customers who come to Zambia to purchase the fish but as production expands EFM intends to begin their own export chain.

This business is designed to operate as a training facility to partner with local farmers in the daily operations. While the current operation maintains 22 employees, the business plan involves turning these employees into stakeholders of the operation. EFM intends to train managers for one (or more) ponds where these managers will also own a 50\% stake. The business also intends to provide technical support, training, and new fish from the hatchery to aid in the development of fish ponds in local townships and villages. Because of the difficulties in transporting and storing the product, this model will essentially aid in the development of a rural fish market where each farmer will serve his or her own geographic market area. Just as with the banana project the fish are sold to women with market stalls, wholesale, at $\$ 3.00$ per kilogram. In the market, these fish are then sold at a price of $\$ 5.00$ per kilogram with this markup accomplishing the income generating goals that EFM has set for the women.

\section{CONCLUSION: LESSONS LEARNED}

EFM has demonstrated a remarkable ability to leverage private donations to achieve development goals and cultivate sustainable revenue streams through their investment into the agribusiness sector. First the practice of developing products with a portfolio of ventures that cater to not only local, but also national and international demand appropriately manages some of the risk associated with operating in a developing country. This strategy also gives the donor long term goals and markets to grow into as supply constraints lessen. Second, EFM has demonstrated a unique strength of agribusiness investment as a means to engage the community and support the incomes of specific groups (women, children) through the wholesale process. This also removes the burden of marketing and retailing from the organization so that donor funds can be spent on actual project investment and value-creation rather than on intangibles such as advertising. Finally, EFM has shown that small scale aid donors should actively participate in the competitive grant process. Few individuals realize the staggering size of the development community and the support there is in sharing information, technical support, and funding through matching programs or outright grants to promote growth in the poorest countries.

\section{AUTHOR INFORMATION}

John R. Ledgerwood, MSA, CPA, CMA, CFM - John Ledgerwood is an Assistant Professor of Accounting at Embry Riddle Aeronautical University, Daytona Beach, Florida, teaching financial and managerial accounting, and international business at both the undergraduate and graduate level. He earned a Master of Science in Accounting from the University of Central Florida, is a Certified Management Accountant, Certified Financial Manager and Certified Public Accountant. He is a Director of Ledgerwood and Zarb, Certified Public Accountants and Associates, PA, Daytona Beach, Florida, and is a Director of Enright Flight Ministries, Inc., a non-profit ministry that serves Central Africa. Born in Newcastle-upon-Tyne, England, Mr. Ledgerwood has worked in the United Kingdom, Central Africa and the United States of America. E-mail: ledgerwj@erau.edu. Corresponding author.

Stephen N. Morgan - Stephen Morgan is a 2011 - 2012 U.S. Fulbright Scholar to Zambia researching economic development through the promotion of small-scale agricultural enterprises. Mr. Morgan graduated from the University of Florida with degrees in Economics, Political Science, and Agricultural Economics. Beginning in 2012, Mr. Morgan will matriculate at Duke University in pursuit of a Ph.D. in Political Science. Research interests include political economy, international development, poverty, and foreign assistance. E-mail: snmorganufl@gmail.com. 


\section{BIBLIOGRAPHY}

1. $\quad$ "Commercial Value Chains in Zambian Agriculture: Do Smallholders Benefit?" (2009). Sustainable Development Department. World Bank.

2. $\quad$ "Enright Flight Ministries Inc. Administrative Staff Interviews 1-17." Personal Interview. August December 2011.

3. Palitza, Kristin. (2011). Why Zambia's presidential election will be all about China. Lusaka Times. Sept 19.

4. Reardon, T. \& Vosti, S. (1995). Links Between Rural Poverty and the Environment in Developing Countries: Asset Categories and Investment Poverty. World Development, 23, 1495-1506.

5. Rural Beneficiary Interviews 1 - 26." Personal Interview. August - December 2011. 